\title{
Technique for lymphocyte transformation
}

\author{
C. R. PENTYCROSS \\ From the Department of Clinical Research, Royal Marsden Hospital \\ and the Institute of Cancer Research, Fulham Road, London
}

SYNOPSIS Current techniques for lymphocyte transformation are evaluated and criticised. A simple technique, designed to meet these criticisms, is described in detail, with particular reference to lymphocyte separation and scoring methods.

Techniques for inducing morphological transformation of lymphocytes to large basophilic blast forms by non-specific mitogens, e.g. phytohaemagglutinin or 'pokeweed', or by specific antigens such as tetanus toxoid, have been described by Hungerford, Donnelly, Nowell, and Beck (1959), Nowell (1960a), Carstairs (1962), Elves and Wilkinson (1963), Coulson and Chalmers (1964), and others.

It will be apparent on surveying the literature that there are wide differences in methods used, particularly those for separating lymphocytes from other leucocytes and the red cells, and also for the number of cells counted. It is not surprising, therefore, that results also vary. For example, the transformation rate for normal phytohaemagglutinin-stimulated lymphocytes is given as $40-50 \%$ by Astaldi, Airo, Lisino, Rodriquez-Paradisi, and Novelli (1966) and $80-95 \%$ by Hirschorn and Schreibman (1964).

\section{METHODS FOR LYMPHOCYTE SEPARATION}

Hungerford et al. (1959) and Nowell (1960a) employed phytohaemagglutinin for the purpose of separating leucocytes from red cells, in which the red cells are agglutinated and centrifugation effects a final separation of the leucocytes but does not separate lymphocytes from other white cells. This method is satisfactory for chromosome analysis. However, in the study of transformation induced by agents other than phytohaemagglutinin or of unstimulated cultures, it is essential that the lymphocytes do not come into contact at all with phytohaemagglutinin since stimulation occurs within 20 minutes (Holt, 1966).

Coulson and Chalmers (1964) have devised a method employing gelatine. This gives a comparatively pure $(96 \%)$ lymphocyte suspension but is

Received for publication 1 May 1967. rather lengthy. Passage through glass wool (Brandt, Börjeson, Nordén, and Olsson, 1962) or glass beads (Schrek and Stefani, 1964) has the same disadvantage. Elves and Wilkinson (1963) have used dextran, but some authorities (Czerski, Szmigielski, and Litwin, 1966) consider this to be toxic.

A method using carbonyl iron and a magnet (Carstairs, 1962) is extremely simple. This method has been compared with the others (Table I) in this laboratory. The same degree of purity of lymphocyte suspension, and a similar transformation score were obtained with each, and iron does not appear to be toxic.

\section{TABLE I}

EFFECT OF POLYMORPH SEPARATION ON LYMPHOCYTE TRANSFORMATION

\begin{tabular}{|c|c|c|c|}
\hline $\begin{array}{l}\text { Polymorph } \\
\text { Separation } \\
\text { Technique }\end{array}$ & $\begin{array}{l}\text { Percentage } \\
\text { Purity of } \\
\text { Lymphocytes }\end{array}$ & $\begin{array}{l}\text { Stimulating } \\
\text { Substance }\end{array}$ & $\begin{array}{l}\text { Percentage } \\
\text { Transformation }\end{array}$ \\
\hline Nil & - & $\begin{array}{l}\text { Nil } \\
\text { Phytohaemagglutinin } \\
\text { Polio vaccine }\end{array}$ & $\begin{array}{r}<1 \\
54 \\
3\end{array}$ \\
\hline $\begin{array}{l}\text { Carbonyl iron } \\
\text { and magnet }\end{array}$ & At least 96 & $\begin{array}{l}\text { Nil } \\
\text { Phytohaemagglutinin } \\
\text { Polio vaccine }\end{array}$ & $\begin{array}{r}<1 \\
51 \\
4\end{array}$ \\
\hline Gelatine & At least 96 & $\begin{array}{l}\text { Nil } \\
\text { Phytohaemagglutinin } \\
\text { Polio vaccine }\end{array}$ & $\begin{array}{r}1 \\
52 \\
2\end{array}$ \\
\hline $\begin{array}{l}\text { Glass wool } \\
\text { column }\end{array}$ & At least 96 & $\begin{array}{l}\text { Nil } \\
\text { Phytohaemagglutinin } \\
\text { Polio vaccine }\end{array}$ & $\begin{array}{r}<1 \\
50 \\
2\end{array}$ \\
\hline
\end{tabular}

However, leaving the polymorphonuclear leucocytes in the culture does not appear to influence the transformation score. This is an important finding, because if the blood has to travel after venepuncture, the ability of the polymorphs to ingest iron is diminished even after two hours. Nevertheless, smears from pure lymphocyte cultures are undoubtedly easier to scan, and in these circumstances another method of separating lymphocytes, although longer, might be preferable. It should be noted that 175 
Oppenheim, Hersh, and Block (1966) have shown that removal of the phagocytic cells does diminish lymphocyte transformation when antigens are used for stimulation, but not if the stimulating substance is phytohaemagglutinin.

Autoradiographic techniques do require a pure lymphocyte suspension, as has been stressed by Cooper (1966), since polymorphs in culture disintegrate, releasing enzymes which degrade thymidine, so making less available for uptake.

\section{CULTURE SERUM}

Lymphocytes can be cultured in the presence of antigen instead of phytohaemagglutinin, after immunizing the patients with such antigens. In these circumstances the use of autologous plasma in the culture introduces a source of variability, because antibodies present after immunization may neutralize the antigen and leave less available for stimulating the lymphocytes. The antibody titre after immunization will not necessarily be the same in every patient. Therefore, although some authors (e.g. Ling and Husband, 1964) use autologous plasma, this is not suitable if accurate quantitation of the results is desired.

Nowell (1961) demonstrated an inhibitory effect of steroids on stimulated lymphocytes. Many patients, under investigation in this laboratory, are receiving steroids and other possibly inhibitory substances. The use of homologous serum which may admittedly contain 'natural' inhibitory substances, at least serves to standardize the culture milieu. Unfortunately, different batches of $\mathrm{AB}$ serum are not all equally efficient in supporting the growth and transformation of lymphocytes. It is therefore essential to test a normal subject's lymphocytes, of known capacity to transform, every time a fresh batch of $\mathrm{AB}$ serum comes into use. However, the lymphocytes from one normal person will not necessarily give a similar transformation score on different occasions, even if the AB serum is from the same batch and the same experimental conditions have been scrupulously observed. To take an extreme example, one normal subject was bled twice in six weeks and the lymphocyte transformation score varied between $38 \%$ and $54 \%$.

Results are poor if the final quantity of fluid is less than $2.5 \mathrm{ml}$, of which $0.5 \mathrm{ml}$ is serum. Most workers use more than this but have not stressed the necessary minimum.

\section{PRESENCE OF RED CELLS}

Most workers attempt to have their cultures entirely free of red cells (RBCs). However, their presence may be advantageous for three reasons:

1 They act as a buffer, so the $p \mathrm{H}$ does not vary more than 6.9-7.1. Nowell (1960b) has demonstrated that the cells' capacity for transformation is not altered between $p \mathrm{H} 6.9$ and 7.6. The presence of red cells thus obviates the necessity for bubbling $\mathrm{CO}_{2}$ into the culture.

2 In the smear (stained by the May-GrünwaldGiemsa method) RBCs act as reference cells for judging the size of neighbouring lymphocytes.

3 Spreading the films is made easier.

\section{COUNTING OF CELLS}

The percentage of cells scored as transformed in a given culture depends on several variables, particu- iv larly the technique for preparing the films from $\vec{v}$ which the counts are made, the actual counting procedure, and the definition of a transformed cell. These basic aspects are often not described with precision, and authors' procedures cannot therefore be repeated.

The most important points, which are often inadequately covered in descriptions of technique, are listed below.

Various cells are found, apart from small lymphocytes and transformed cells. In this laboratory six cell types are recognized, described in detail in the section on technique. Many authors quote percentage transformation without stating the nature of the population of cells counted. Phytohaemagglutinin produces a marked clumping effect on the lymphocytes, rendering a large proportion of cells morphologically unrecognizable. There are various ways of making the smears which produce varying distributions of small and transformed lymphocytes. Scanning the smear depends on the method of spreading, and must obviously be done in such a way that a representative population is surveyed. This aspect is glossed over by many workers. The total number of cells counted varies considerably. Elves and Wilkinson (1963) count 200 cells; Moynihan, Jackson, and Hardy (1965) count 1,000 cells but admit this to be inadequate; Nowell (1961) counts 2,000 cells. Many authors omit to mention how many cells are counted. Chalmers (1965) has found that at least 4,000 cells must be counted for the results to be considered reliable. This figure was based on confidence curves which showed that lower figures were inadequate.

With these points in mind, the following method has been evolved, which in addition to redressing these errors, also ensures enough movement during culture to reduce the intensity of the clumping without undue trauma. Up to the time of harvesting, 
sterile conditions are maintained. The $p \mathrm{H}$ of the mixture is tested both before and after culture.

\section{MATERIALS}

Heparin (mucous) injection BP 1,000 units $/ \mathrm{ml}$. (Weddel Pharmaceuticals, London); carbonyl iron powder S.F. $3 \mu$ size (Fine Dyestuffs and Chemicals Ltd., Manchester); magnet broad-based horse-shoe (Eclipse) $3.4 \times 4.4 \times$ $2.7 \mathrm{~cm}$ (available retail); AB serum, homologous human, (South London Blood Transfusion Service, Sutton); tissue culture medium 199 (penicillin containing 200 units/ml, streptomysin $100 \mu \mathrm{g} / \mathrm{ml}$ ) (Glaxo Laboratories Ltd., Greenford); phytohaemagglutinin, 'Wellcome' brand, $5 \mathrm{ml}$ dried (Wellcome Research Laboratories, Beckenham). After reconstituting with $5 \mathrm{ml}$ sterile distilled water, the preparation will keep for a maximum of 28 days at $4^{\circ} \mathrm{C}$. Poliomyelitis vaccine (oral) BP, trivalent Sabin type, Wellcome brand (Burroughs Wellcome \& Co., London).

WHEEL Roller tube tissue culture apparatus. Diameter $38 \mathrm{~cm}$. $1 \mathrm{rev} / 7$ minutes (Matburn Ltd., 20-24 Emerald Street, London, W.C.1).

TEST PAPERS $p \mathrm{H}$ 6:8-8.3. (Johnsons of Hendon Ltd.)

CENTRIFUGE with slow speed rheostat and timer. M.S.E. Minor (Measuring and Scientific Equipment Ltd., 25-28 Buckingham Gate, London, S.W.1).

\section{METHOD}

Venous blood, $20 \mathrm{ml}$, is placed in a universal container containing 250 units of phenol-free heparin. The blood is left to stand for one hour at room temperature and the leucocyte-rich supernatant pipetted into a second universal container. The remaining blood is centrifuged at $25 \mathrm{~g}$ for five minutes. The supernatant from this, together with the buffy coat and enough RBCs to impart a reddish tinge, are pipetted into the leucocyte-rich plasma. A pinch of carbonyl iron is added to the plasma which is then incubated for 20 minutes at $37^{\circ} \mathrm{C}$. At fiveminute intervals during this time, the container is gently shaken. The container is removed from the incubator and stood on the magnet for five minutes. The supernatant is pipetted into another universal container; more than $90 \%$ of the white cells will be lymphocytes. The procedure with the magnet and the pipetting are repeated twice. A white cell count is performed. The cells are washed three times in sterile 'normal' saline. After pipetting off the final saline supernatant enough homologous human AB serum is added (previously warmed to room temperature to avoid thermal shock) to give a lymphocyte concentration of $5 \times 10^{6} / \mathrm{ml}$. Four times this amount of TC 199 is added, and the culture thoroughly but gently mixed. The TC 199 should also have been warmed to room temperature. The mixture is put into the appropriate number of centrifuge tubes. For instance, if a phytohaemagglutinin and poliomyelitis antigen culture are being set up, four tubes will be needed to allow two tubes to have no mitogen or antigen added. These act as controls. Phytohaemagglutinin or the specific antigen is added to the appropriate tubes. For phytohaemagglutinin, $0.05 \mathrm{ml}$ of reconstituted material is mixed with $0.45 \mathrm{ml}$ of sterile saline, and all this is added to a $10 \mathrm{ml}$ culture or less in proportion. For poliomyelitis, the best results are obtained in our laboratory if $0.04 \mathrm{ml}$ of oral poliomyelitis vaccine is added to the $10 \mathrm{ml}$ culture or less in proportion. The tubes are placed $\left(\right.$ at $37^{\circ} \mathrm{C}$ ) horizontally on a slowly revolving slotted wheel, and left for 72 hours in the case of a phytohaemagglutinin culture, and one control culture, or 90 hours in the case of a specific antigen (e.g. poliomyelitis) culture, and one control culture.

At the end of the appropriate period, the tubes are removed from the wheel and allowed to stand vertically at $37^{\circ} \mathrm{C}$ for half an hour. The tubes are removed to room temperature and centrifuged at $18 \mathrm{~g}$ for five minutes. The supernatant is discarded, the cell button gently mixed in the minimum remaining supernatant, and spread on a glass slide in the manner described by Dacie and Lewis (1963) for peripheral blood. The smears are stained by the May-Grünwald-Giemsa method.

\section{SCORING}

Six main categories of cell are found: (1) obvious mitotic figures; (2) classical transformed cells having a stippled nuclear chromatin, visible nucleoli, and abundant deeply basophilic cytoplasm. They are usually, but not invariably, large $(20-40 \mu)$; (3) large bizarre cells with a degenerating nucleus, nucleolar remnants and abundant but pale and ragged cytoplasm. It is concluded that these cells have transformed and died; (4) classical small and medium lymphocytes; (5) as 4 , but with an amorphous
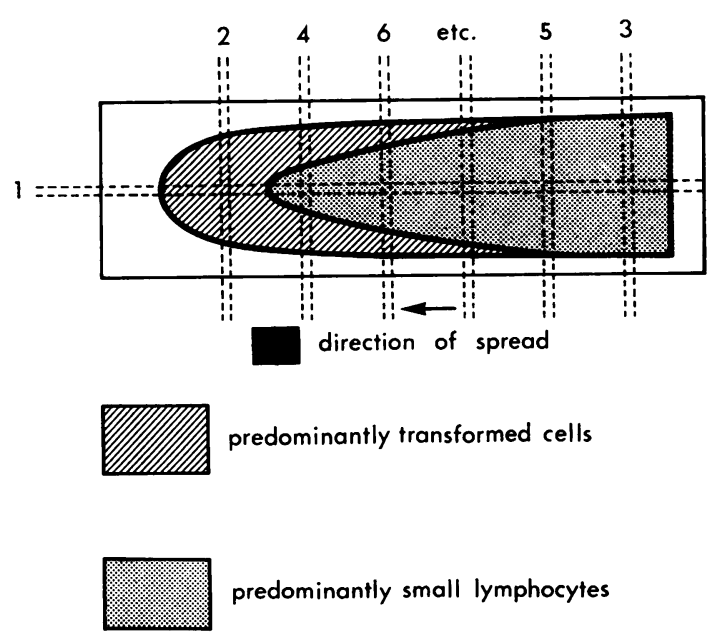

FIG. 1. Recommended method of counting cells in a smear made after culture. Numbers indicate order of surveying strips until 4,000 lymphocytes have been counted. 
nucleus, so these are regarded as having died in culture without transforming; (6) basket cells.

Usually about $90 \%$ of cells belong to categories 2 and 4. Occasional difficulties arise in some patients with chronic lymphocytic leukaemia whose peripheral blood smear shows atypical lymphocytes having some of the attributes of transformed cells.

Figure 1 shows the pattern of distribution of the small and medium lymphocytes, and of the transformed cells and the method of scanning the strips until a total of 4,000 lymphocytes have been counted. The transformation score (cells of categories 1-3 inclusive) is that from the specific stimulated culture under considerat $\mathrm{n}$, minus the score from the control culture. A small number of cells will still be unrecognizable as belonging to a particular category and must then be ignored. A few cells will inevitably be counted twice.

\section{SUMMARY}

The technique described above has specifically corrected the following sources of variability. Washing the lymphocytes and using homologous serum has obviated difficulties concerned with antibodies and possibly inhibitory drugs. Inclusion of red cells has made spreading the film and judgment of lymphocyte size easier, as well as rendering the cumbersome procedure of bubbling $\mathrm{CO}_{2}$ into the culture superfluous. Clumping of cells in phytohaemagglutinin cultures has been minimized by using the wheel. A larger proportion of cells are subsequently recognizable morphologically. The cells have been counted in a systematic manner, bearing in mind the areas where each cell type is found, and the necessary total for accurate results. Iron separation of lymphocytes has the advantages of speed and simplicity of equipment, but is not otherwise claimed to be superior to other methods.

I am indebted to Dr. Sylvia Lawler and to Dr. D. A. G. Galton for much helpful advice with the work and with this manuscript. I have received many valuable suggestions but would especially like to thank Professor J. L. Gowans, Dr. D. G. Chalmers, Mr. A. S. Coulson, and Dr. K. B. Roberts. The assistance of Miss L. Pegus, who drew the diagram, is greatly appreciated.

I gratefully acknowledge the receipt of a grant from the Leukaemia Research Fund Ltd., in support of this work.

I am most grateful to the South London Blood Transfusion Service for supplying AB serum.

\section{REFERENCES}

Astaldi, G., Airò, R., Lisino, T., Rodriquez-Paradisi, E., and Novelli, ì E. (1966). Lancet, 2, 502.

Brandt, L., Börjeson, J., Nordén, A., and Olsson, I. (1962). Acta med. scand., $172,459$.

Carstairs, K. (1962). Lancet, 1, 829.

Chalmers, D. G. (1965). Personal communication.

Cooper, E. H. (1966). Lancet, 1, 51.

Coulson, A. S., and Chalmers, D. G. (1964). Ibid., 1, 468.

Czerski, P., Szmigielski, S., and Litwin, J. (1966). Vox Sang., 11, 734.

Dacie, J. V., and Lewis, S. M. (1963). Practical Haematology. 3rd ed. $\frac{\widehat{\rho}}{\supset}$ Churchill, London.

Elves, M. W., and Wilkinson, J. F. (1963). Exp. Cell. Res., 30, 200. Hirschhorn, K., and Schreibman, R. R.(1964). J. clin. Invest., 43, 1273. Holt, P. J. L. (1966). In The Biological Effects of Phytohaemagglutinin. Published by the Robert Jones and Agnes Hunt Orthopaedic Hospital Management Committee, Oswestry.

Hungerford, D. A., Donnelly, A. J., Nowell, P. C., and Beck, S. (1959). Amer. J. hum. Genet., 11, 215.

Ling, N. R., and Husband, E. M. (1964). Lancet, 1, 363.

Moynihan, P. C., Jackson, J. F., and Hardy, J. D. (1965). Ibid., 1, 453.

Nowell, P. C. (1960a). Exp. Cell. Res., 19, 267.

(1960b). Cancer Res., 20, 462.

(1961). Ibid., 21, 1518.

Oppenheim, J. J., Hersh, E. M., and Block, J. B. (1966). In The Biological Effects of Phytohaemagglutinin. Published by the Robert Jones and Agnes Hunt Orthopaedic Hospital Management Committee, Oswestry.

Schrek, R., and Stefani, S. (1964). J. nat. Cancer Inst., 32, 507. 